\title{
Meta-Analysis of the Impact of Psychological Capital on Quality of Work Life and Organizational Citizenship Behavior: A Study on Sadat City University
}

\author{
Wageeh Nafei ${ }^{1}$ \\ ${ }^{1}$ University of Sadat City, Menoufia, Egypt \\ Correspondence: Wageeh Nafei, University of Sadat City, Menoufia, Egypt. E-mail: dr.wageeh1965@yahoo.com
}

Received: August 3, 2014

Accepted: December 9, $2014 \quad$ Online Published: February 20, 2015

doi:10.5430/ijba.v6n2p42

URL: http://dx.doi.org/10.5430/ijba.v6n2p42

\begin{abstract}
Background: Psychological Capital (PsyCap) was recently identified as a core construct in the literature. However, there is considerably less evidence on its effects on Quality of Work Life (QWL) and Organizational Citizenship Behavior (OCB).

Purpose: The objective of this study is to provide empirical evidence on the relationships between PsyCap, QWL and OCB. This paper also seeks to present the theoretical development of PsyCap, QWL, OCB and their application to employees at Sadat City University practices.

Research Design/Methodology: The method is to assess positive PsyCap (PsyCap Questionnaire, Luthans et al., 2006), QWL (QWL Survey Seashore et al., 1983; Cammann, et al., 1983; National Institute for Occupational Safety and Health, 2002), OCB (OCB Questionnaire Podsakoff, 1990; Konovsky \& Pugh, 1994; and Konovsky \& Organ, 1996). Out of the 682 questionnaires that were distributed, 315 usable questionnaires were returned, a response rate of $46 \%$.

Findings: It has been revealed to how PsyCap factors such as hope, optimism, resiliency and self-efficacy have an impact on QWL and OCB. In other words, hope, optimism, resiliency and self-efficacy significantly correlated with QWL and OCB.

Practical implications: The study suggests that the University of Sadat City in Egypt can improve QWL by influencing its PsyCap. The study provided that it is necessary to pay more attention to the dimensions of PsyCap as a key source for organizations to enhance the competitive advantage which is of prime significance for QWL and OCB.

Originality/value: The study observes that there is a critical shortage of PsyCap and that a greater understanding of the factors that influence the QWL and OCB is of great importance. Therefore, this study is to examine the relationship between PsyCap, QWL and OCB among employees at Sadat City University in Egypt.
\end{abstract}

Keywords: psychological capital, quality of work life, organizational citizenship behavior

\section{Introduction}

In 1999 the new science of positive psychology emerged thanks to its founder Martin Seligman, president of the American Association of Psychology at this time. The aim of this science is to enhance self-efficacy of the individual, focus on how to exploit the strengths rather than on weaknesses, look for opportunities instead of looking for threats, and, generally, activate functional, efficient and holistic health for the employee rather than focusing on disorders and treatment (Seligman, 2002). Recently, Barack Obama was not to gain the U.S. presidency but for his courage and hope in the future, high confidence in himself, optimism in the ability to manage the country, as well as his ability to adapt to the economic, social and political challenges. So he wrote a book called "The Audacity of Hope" and all these qualities represent components of PsyCap (Avey, et al., 2011).

\section{Conceptual Background}

\subsection{Psychological Capital}

It is interested in positive psychology to study how to maximize investment in human resources, the welfare of the individual and the optimal investment for his abilities, by expanding the use of psychology in alleviating the problems that may encounter an individual in the work environment (Avey, et al., 2010). 
The positive outlook gained interest of many researchers in the management of human resources, because of its positive impact on many variables, personal and organizational, such as productivity, motivation, job performance, organizational commitment, OCB, and the quality of work life (Sin \& Lyubomirsky, 2009; Mortazavi, et al., 2012 Etebarian, et al., 2012).

Some affirm the importance of the role of PsyCap in reducing the level of stress and pressures of the individual, and thus reduce the consequences of the additional costs incurred by the organization (Avey, et al., 2008).

Many organizations focus on the development of the PsyCap of their employees as it is one of the most important factors that can raise the level of productivity and support the competitiveness of the organizations (Luthans \& Youssef, 2004).

PsyCap can, therefore, be defined as the positive potentials an individual has. It can be harnessed for self-development, reflected on his behavior in order to enhance the competitiveness of the organization. This is to be attained through recruitment of the positive potentials in self-development (Luthans, et al., 2005).

It must be noted that the emergence of PsyCap as a new approach in the management of human resources has enabled managers to take advantage of it to invest in effective capacities of subordinates, and that by focusing on the positive aspects of workers rather than on weaknesses, which is beneficial to both the worker and the organization (Luthans, et al., 2006).

\subsection{The Basic Components of PsyCap}

Most of the previous studies suggest that PsyCap consists of four basic dimensions as follows (Luthans, et al., 2008).

\subsubsection{Hope}

Hope can be defined as a case of positive stimulus about the future and is based on the individual's sense of Interactive success, which consists of (1) the will, which is the potential energy of the individual that enables him to achieve the target, (2) the existence of alternative pathways to reach the target, which refers to the multiplicity of the individual available alternatives to ensure access to the target. Although the studies of hope did not receive sufficient attention in the work environment, the results indicate a correlation between the level of availability of hope among the workers and some of the wanted trends within the work environment, such as job satisfaction, and job embeddedness, worker psychological health, and the extent of his feelings of happiness while doing his job. Therefore, training efforts in contemporary organizations have become focused on the development and giving of hope in the hearts of workers, and training them on how to formulate their goals, and increase their ability to develop alternative routes that would enable them to reach their goals and provide support and assistance to them in the case of the emergence of obstacles (Luthans, et al., 2008; \& Youssef \& Luthans, 2007).

In light of this, the importance of the role that hope can play emerges as it influences the trends of workers (job satisfaction, organizational commitment) on the one hand, and the functionality of the workers on the other hand. The researcher expects that the high levels of hope among the workers can contribute to increase the levels of job satisfaction, organizational commitment and therefore their level of functioning within the organization.

\subsubsection{Resilience}

Resilience is the positive reaction shown by the individual when exposed to crises and problems (Masten \& Reed, 2002). Resilience can be defined as workers' positive potential psychological energy, which enables them to get a bounce back to the normal case during exposure to a specific problem in the work environment. The results of the previous studies indicate an importance of the existence of a minimum level of resilience to the individual, as it plays an important role in influencing the increase of the rates of job satisfaction and organizational commitment, as well as the feeling of happiness and psychological comfort (Larson \& Luthans, 2006; Youssef \& Luthans, 2007).

Hence, it is clear that the individual's capacity for resilience and adaptation in sense of their former conception does affect the level of job satisfaction and organizational commitment, and therefore the level of functionality, as individuals who have a high capacity for resilience and to cope with the problems that occur within the organization may have increased feelings of satisfaction and organizational commitment. Therefore, the level of their functioning within the organization is higher.

\subsubsection{Optimism}

The level of optimism of any individual is due to certain reasons, including a set of properties and relatively stable positive qualities he has. The optimistic man realizes ordeal as a temporary setback and that the chance of a new start is still available. Therefore, the level of optimism of the individual affects his performance, as well as the level of sense of happiness and job satisfaction (Luthan et al., 2005; Youssef \& Luthans, 2007). 
In light of the previous view, we can say that the level of optimism of the individual affects the level of ability to deal with adverse events within the organization. The researcher expects that the high levels of optimism among workers can affect the level of their sense of happiness and job satisfaction, organizational commitment, and therefore the level of performance of the individual within the organization.

\subsubsection{Self-efficacy}

Self-efficacy is the conviction of the individual of his ability to develop internal motivation and recruitment of his cognitive resources to identify alternatives that would enable him to act to achieve a particular task successfully. The self-efficacy is a criterion for the beliefs of ability, as the individual's belief of his inability to do something is an index of low self-efficacy. Some argue that self-efficacy plays a vital role in maintaining high levels of performance of the individual, even in the most difficult circumstances, and that self-efficacy raises some sort of positive thinking to the individuals. (Norman et al, 2010).

In light of the above, it can be said that the higher the level of the individual' self-efficacy, the higher the level of his achievement is, and the higher is his desire to make more effort to perform the work. The level of his steadfastness in the face of the problems facing him to reach objectives is also higher.

\subsection{Quality of Work Life}

Quality of Work Life (QWL) is a concept of behavioral science, and the term was first introduced by Davis in 1972 (Mathur, 1989; Hian \& Einstein, 1990). QWL can be defined as a process by which an organization responds to employee needs by developing mechanisms to allow them to share fully in making the decisions that design their lives at work. QWL is a philosophy, a set of principles, which holds that people are the most important resource in the organization as they are trustworthy, responsible and capable of making valuable contribution and they should be treated with dignity and respect (Robbins, 1989).

The key elements of QWL in the literature include job security, job satisfaction, better reward system, employee benefits, employee involvement and organizational performance (Havlovic, 1991). Studies demonstrate that employees with high QWL tend to report high levels of identification with their organizations, job satisfaction, job performance and lower levels of turnover and personal alienation (Efraty, et al., 1991).

QWL is defined as employee satisfaction with a variety of needs through resources, activities, and outcomes stemming from participation in the workplace (Sirgy \& et al. 2001).

QWL has been well recognized as a multi-dimensional construct and it may not be universal or eternal. The key concepts captured and discussed in the existing literature include job security, better reward systems, higher pay, opportunity for growth, participative groups, and increased organizational productivity. In the scientific management tradition, satisfaction with QWL was thought to be based solely on "extrinsic" traits of the job: salaries and other tangible benefits, and the safety and hygiene of the workplace. By contrast, the human relations approach stresses that, while extrinsic rewards are important, "intrinsic rewards" are key predictors of productivity, efficiency, absenteeism and turnover. These intrinsic rewards include traits specific to the work done, the "task content": skill levels, autonomy and challenge (Beauregard, 2007).

One conceptualization of QWL, based on need-hierarchy theory of Maslow, regards QWL as employee satisfaction of seven sets of human developmental needs: (1) health and safety needs, (2) economic and family needs, (3) social needs, (4) esteem needs, (5) actualization needs, (6) knowledge needs, and (7) esthetic needs (Marta et al, 2011).

In sum, QWL is defined as the favorable condition and environment of employees benefit, employees' welfare and management attitudes towards operational workers as well as employees in general.

There are eight aspects in which employees' perceptions towards their work organizations could determine their QWL: adequate and fair compensation; safe and health environment; development of human capacities; growth and security; social integrative constitutionalism; the total life space and social relevance (Walton, 1974).

There much literature highlighting the factors critical for the assessment of QWL (Srinivas, 1994). Comprehensive delineation of the QWL concept is found in three major works. Other researchers have attempted to measure QWL in a variety of settings using combinations of various questionnaires such as job satisfaction, organizational commitment, alienation, job stress, organizational identification, job involvement and finally work role ambiguity, conflict, and overload were studied as proxy measures of QWL (Levine et al., 1984). The key concepts captured in QWL include job security, better reward systems, higher pay, opportunity for growth, and participative groups among others (Straw \& Heckscher, 1984).

QWL can be measured by the feelings that employees have towards their jobs, colleagues, and companies would enhance a chain effect leading to organization's growth and profitability (Heskett, et al., 1997). 
According Robins (1995) QWL is a process by which an organization responds to employee needs by developing mechanisms to allow them to share fully in making the decisions that design their lives at work. The key elements of QWL in the literature include job security, job satisfaction, better reward system, employee benefits, employee involvement and organizational performance (Scobel, 1975).

For the purpose of this study, QWL is defined as the favorable condition and environment of employees benefit, employees' welfare and management attitudes towards operational workers as well as employees in general.

\subsection{Organizational Citizenship Behavior}

Bateman and Organ (1983) were the first to use the term "OCB" in 1983 (Podsakoff et al, 2000). OCB is one of the most widely studied topics in organizational behavior research (Podsakoff \& MacKenzie, 1997; Ehrhart \& Naumann, 2004).

OCB is one of the emerging management concepts that are being emphasized for the organizational effectiveness, efficiency and profitability of the organizations (Ertürk, et al. 2004). OCB is an extra role and behaviours such as teamwork with employees, approaching workplace earlier and leaving late, helping other employees, using organizational possessions with care, disseminating positively in organization (Turnispeed \& Rassuli, 2005).

OCB can improve co-worker and managerial productivity, provide superior efficiency in resource use and allocation, reduce managerial expenses, provide better coordination of organizational activities across individuals, groups and functional departments, improve organizational attractiveness for high quality new recruits, increase stability in the organization's performance, enhance organizational capability to adapt effectively to environmental changes (Cohen \& Vigoda, 2000).

OCB is individual behavior that is discretionary, not directly or explicitly recognized by the formal reward system, and that in the aggregate promotes the effective functioning of the organization. OCB can be defined as behaviors that are not formally rewarded is equally too broad, as few "in-role" behaviors actually guarantee a formal reward. High levels of OCB should lead to a more efficient organization and help bring new resources into the organization. In Organ's explanation, securing needed resources refers not only to the attraction of new members or raw materials, but also to such intangible factors as company good will, or the external image and reputation of the organization. Thus, customer perceptions of the organization's products or services could be an external assessment of effectiveness influenced by OCB (Organ, 1988).

OCB can assist organizations to develop performance and increase competitive periphery as it encourages employees to perform beyond the formal job requirement. It can assist the organization to be successful in current environment and accelerate novelty and creative approaches for organizations (Nemeth \& Staw, 1989).

OCB can be classified into two groups. They are OCB-Organizational and OCB Individual. OCB-Organizational benefits the organization in general, such as adhering to informal rules devised to maintain order. OCB-Individual benefits specific individuals and indirectly contribute the organization, such as taking a personnel interest in other employees (Williams \& Anderson, 1991).

OCB is individual behaviours that promote the good of the organization by contributing to its social and psychological environment. Such behaviours include helping another employee finish a project, providing helpful advice or suggestions, and offering positive feedback on work tasks (Podsakoff, et al., 1993).

OCB has been related to wide range of antecedents such as job satisfaction, leadership, fairness, perceived organizational support, psychological contract, and commitment (Ravichandran, et al., 2007).

OCB is referred to as "contextual performance" or "prosocial organizational behaviour" to emphasize the voluntary nature of the activity and to distinguish it from "task performance" or one's assigned duties (Borman \& Motowidlo, 1993).

There are some features of OCB. They are (1) beneficial and informal behavior or gestures, (2) discretionary; not enforceable requirement of the role or job description, (3) not directly or explicitly recognized by formal reward system; uncompensated individual contributions in the workplace that does role requirement, and (4) enhances the effective functioning of the organizations in the aggregate (Paine \& Organ, 2000).

Organ (1988) identified five categories of OCB (1) Altruism: the helping of an individual coworker on a task, (2) Courtesy: alerting others in the organization about changes that may affect their work, (3) Conscientiousness: carrying out one's duties beyond the minimum requirements, (4) Sportsmanship: refraining from complaining about trivial matters, and (5) Civic Virtue: participating in the governance of the organization. There are five dimensions of OCB. They are as follows (Organ, 1988; Podsakoff et al, 1990): 
1. Altruism can be called simply helping or helpfulness. Altruism consists of voluntarily actions that help others with an organizationally relevant task such as voluntarily helping orientation of a new employee, sharing sales strategies, teaching employees useful knowledge or skills, showing employees how to accomplish difficult tasks (Borman et al., 2001). Altruism (e.g., helping new colleagues and freely giving time to others) is naturally concentrating toward other individuals but adds to group efficiency by increasing the performance of individuals.

2. Conscientiousness is a discretionary behavior that goes well beyond the minimum role requirement level of the organization, such as obeying rules and regulations, not taking extra breaks, working extra-long days (MacKenzie et al, 1993). More conscientiousness for an employee means more responsibility and less supervision (Podsakoff \& MacKenzie, 1997). Altruism and conscientiousness are the two major or overarching dimensions of OCB (Borman et al., 2001). Conscientiousness (e.g., efficient use of time and going beyond minimum expectations) increases the efficiency of the individual and the group.

3. Sportsmanship is demonstration of willingness to tolerate minor and temporary personnel inconveniences and impositions of work without grievances, complaints, appeals, accusations, or protest, thus conserving organizational energies for task accomplishment and lightening the loads of managers (Organ \& Ryan, 1995). Sportsmanship (e.g., avoiding complaining and whining) improves the quantity of time spent on productive activities in the organization.

4. Courtesy, or gesture, is demonstrated in the interest of preventing creations of problems for co-workers. A courteous employee avoiding creating problems for co-workers reduces intergroup conflict so managers do not fall into a pattern of crisis management (Podsakoff \& MacKenzie, 1997). Courtesy (e.g., advance notices, reminders, and communicating appropriate information) facilitates avoidance of problems and boosts productive use of time.

5. Civic Virtue is a behavior on the part of an individual that indicates that the employee responsibly participates in, is involved in, or concerned about the life of the company (Podsakoff et al, 1990). This dimension represents a macro level interest in, or commitment to the organization. This behavior shows willingness to participate actively in managerial events, to monitor organization's environment for threats and opportunities, to look out for organization's best interest. These behaviors reflect an employee's recognition of being a part organization (Podsakoff et al, 2000). Civic Virtue (e.g., serving to communities and voluntarily attending functions) endorses the interests of the organization.

Each dimension of OCB offers a different rationale for this relationship. Altruism or helping coworkers makes the work system more productive because one worker can utilize his or her free time to assist another on a more urgent task. Acts of civic virtue may include offering suggestions for cost improvement or other resource saving ideas, which may directly influencing efficiency. To a lesser extent, conscientious employees, as well as those who avoid personal gain or other negative behaviors, demonstrate compliance with company policies and maintain predictable, consistent work schedules, increasing the reliability of the service. As reliability increases, the costs of rework are reduced, making the unit more efficient (Berry \& Parasuraman, 1991).

\section{Research Model}

The proposed comprehensive conceptual model is presented in Figure 1. The diagram below shows that there is one independent variable of PsyCap. There are two dependent variable of QWL and OCB. It shows the rational link among the variables. From the above discussion, the research model is as shown in Figure 1 below.

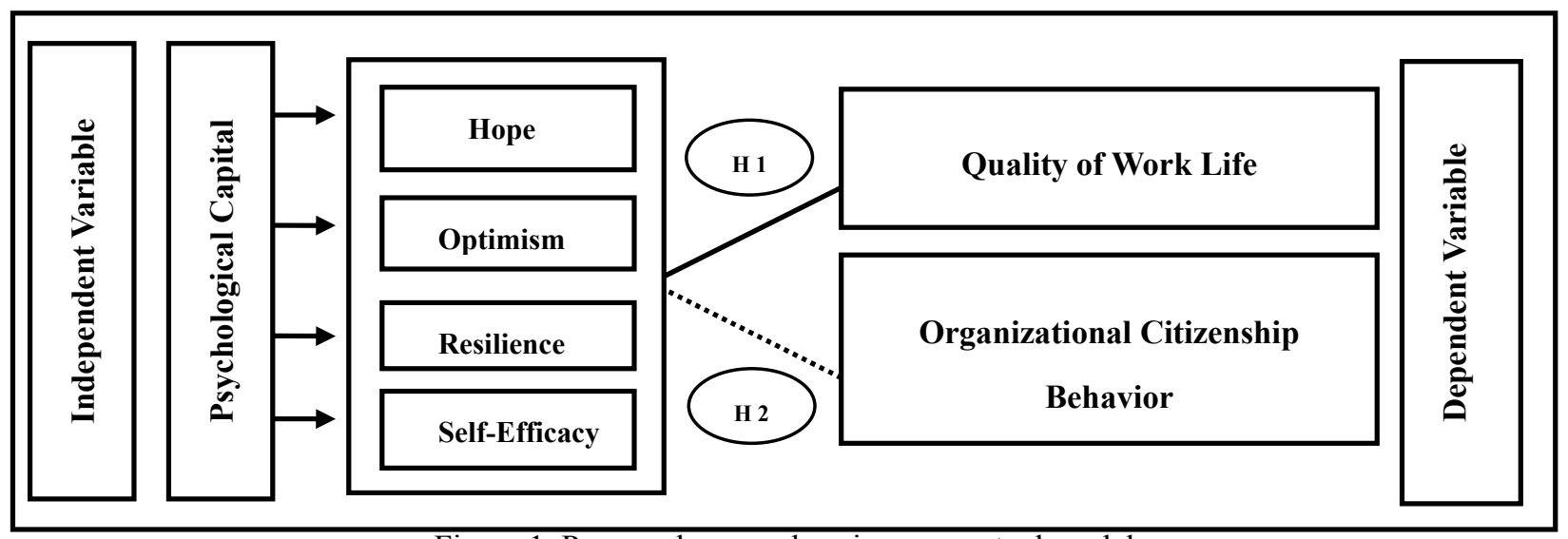

Figure 1. Proposed comprehensive conceptual model 
The research framework suggests that PsyCap have an impact on QWL and OCB. PsyCap as measured consists of hope, optimism, resilience and self-efficacy (Luthans, 2006). QWL is measured in terms of the moral conditions of the work environment, job characteristics, wages and rewards, team work, head's method in supervision, and participation in decision-making (Seashore et al., 1983; Cammann, et al., 1983; National Institute for Occupational safety and Health, 2002). OCB is measured in terms of altruism, courtesy, sportsmanship, conscientiousness, and civic virtue (Podsakoff, 1990; Konovsky \& Pugh, 1994; and Konovsky \& Organ, 1996).

\section{Research Questions and Hypotheses}

The researcher found the research problem through two sources. The first source is to be found in previous studies, and it turns out that there is a lack in the number of literature reviews that dealt with the analysis of the relationship between PsyCap, QWL and OCB for employees at Sadat City University in Egypt. This called for the researcher to test this relationship in the Egyptian environment.

The second source is the pilot study, which was conducted in an interview with (30) employees at Sadat City University in Egypt in order to identify the relationship between PsyCap, QWL and OCB at Sadat City University in Egypt. The researcher found through the pilot study several indicators; notably the important and vital role that could be played by PsyCap in developing and improving QWL and OCB at Sadat City University in Egypt

The research process includes both questions and hypotheses. The research questions of this study are as follows:

Q1: What is the nature and the extent of the relationship between PsyCap (Hope, Optimism, Resiliency, and Self-efficacy) and QWL at Sadat City University in Egypt.

Q2: What is the statistically significant relationship between PsyCap (Hope, Optimism, Resiliency, and Self-efficacy) and OCB at Sadat City University in Egypt.

The following hypotheses were developed to test if there is a significant correlation between JE, QWL and OCB at Sadat City University in Egypt.

H1: PsyCap (Hope, Optimism, Resiliency, and Self-efficacy) of employees has no statistically significant effect on QWL at Sadat City University in Egypt.

H2: PsyCap (Hope, Optimism, Resiliency, and Self-efficacy) of employees has no statistically significant relationship with OCB at Sadat City University in Egypt.

\section{Research Methods}

\subsection{Research Population}

The study subjects are employees at Sadat City University in Egypt. The total population is 692 employees. The research population is illustrated in the following table:

Table 1. Distribution of the population

\begin{tabular}{lcc}
\hline \multicolumn{1}{c}{ Faculty Members } & Number & Percentage \\
\hline Faculty of Veterinary Medicine & 137 & $19.8 \%$ \\
Faculty of Tourism \& Hotels & 89 & $12.9 \%$ \\
Genetic Engineering Research Institute & 117 & $16.9 \%$ \\
Faculty of Physical Education & 174 & $25.1 \%$ \\
Faculty of Education & 33 & $4.8 \%$ \\
Faculty of Commerce & 55 & $7.9 \%$ \\
Faculty of Law & 43 & $6.2 \%$ \\
Institute for Environmental Studies and Research & 44 & $6.4 \%$ \\
\hline \multicolumn{1}{c}{ Total } & $\mathbf{6 9 2}$ & $\mathbf{1 0 0 \%}$ \\
\hline
\end{tabular}

Source: Staff Members Affairs Department, Sadat City University, Egypt, 2014

Due to the small number of members of the research community at Sadat City University, it was decided to study this community using comprehensive inventory (Complete Numeration or Census) in order to get the highest percentage of survey lists. Table 2 illustrates features of sample units. 


\subsection{Method of Data Collection}

The goal of this study was to examine the relationships between PsyCap, QWL and OCB at Sadat city University in Egypt. A survey research method was used to collect data in this study.

The questionnaire included four questions, relating to PsyCap, QWL, OCB and biographical information of employees at Sadat City University in Egypt.

A total of 682 questionnaires were sent out in May, 2014 and collected in July 2014. Three hundred and fifty effective questionnaires were collected $(51 \%$ collection rate). Thirty five ineffective ones (with unanswered questions, duplicated entries and inappropriate marks) were excluded, and the number of effective ones was 315 (46\% valid collection rate).

Table 2. Characteristics of the sample units

\begin{tabular}{|c|c|c|c|}
\hline \multicolumn{2}{|c|}{ Variables } & Number & Percentage \\
\hline \multirow{3}{*}{ 1-Sex } & Male & 200 & $63.5 \%$ \\
\hline & Female & 115 & $36.5 \%$ \\
\hline & Total & 315 & $100 \%$ \\
\hline \multirow{6}{*}{ 2- Academic Degree } & Professor & 60 & $19.5 \%$ \\
\hline & Associate professor & 80 & $25.4 \%$ \\
\hline & Assistant professor & 120 & $38.1 \%$ \\
\hline & Lecturer & 20 & $6.3 \%$ \\
\hline & Demonstrator & 35 & $11.1 \%$ \\
\hline & Total & 315 & $100 \%$ \\
\hline \multirow{3}{*}{ 3- Marital Status } & Married & 220 & $69.8 \%$ \\
\hline & Single & 95 & $30.2 \%$ \\
\hline & Total & 310 & $100 \%$ \\
\hline \multirow{4}{*}{ 4- Age } & Less than 30 years & 60 & $19.0 \%$ \\
\hline & From 30 to 45 & 190 & $60.3 \%$ \\
\hline & More than 45 & 65 & $20.7 \%$ \\
\hline & Total & 315 & $100 \%$ \\
\hline \multirow{4}{*}{ 5- Period of Experience } & Less than 5 years & 130 & $41.3 \%$ \\
\hline & From 5 to 10 & 145 & $46.0 \%$ \\
\hline & More than 10 & 40 & $12.7 \%$ \\
\hline & Total & 315 & $100 \%$ \\
\hline
\end{tabular}

\subsection{Research Variables and Methods of Measuring}

The 24-item scale PsyCap section is based on Luthans, 2006. There were six items measuring hope, six items measuring optimism, six items measuring resilience, and six items measuring self-efficacy.

The 36-item scale QWL section is based on Seashore et al., 1983; Cammann, et al., 1983; National Institute for Occupational Safety and Health, 2002. There were six items measuring the moral conditions of the work environment, six items measuring job characteristics, six items measuring wages and rewards, six items measuring team work, six items measuring the head's method in supervision, and six items measuring the participation in decision-making.

The 15-item scale OCB section is based on Podsakoff, (1990), Konovsky \& Pugh (1994), and Konovsky \& Organ (1996). There were three items measuring altruism, three items measuring courtesy, three items measuring sportsmanship, three items measuring conscientiousness, and three items measuring civic virtue. 
Responses to all items scales were anchored on a five (5) point Likert scale for each statement which ranges from (5) "full agreement," (4) for "agree," (3) for "neutral," (2) for "disagree," and (1) for "full disagreement."

\subsection{Methods of Data Analysis and Testing Hypotheses}

The researcher has employed the following methods: (1) The Alpha Correlation Coefficient (ACC), (2) Multiple Regression Analysis (MRA), and (3) the statistical testing of hypotheses which includes F- test and T-test.

\section{Hypotheses Testing}

Before testing the hypotheses and research questions, descriptive statistics were performed to find out means and standard deviations of PsyCap, QWL and OCB.

Table 3. The mean and standard deviations of PsyCap, QWL and OCB

\begin{tabular}{llcc}
\hline \multirow{2}{*}{ Variables } & \multicolumn{1}{c}{ The Dimension } & Mean & $\begin{array}{c}\text { Standard } \\
\text { Deviation }\end{array}$ \\
\hline \multirow{3}{*}{ PsyCap } & Hope & 3.30 & 1.16 \\
& Optimism & 3.24 & 1.01 \\
& Resilience & 3.45 & 0.98 \\
& Self-Efficacy & 3.60 & 0.97 \\
\cline { 2 - 4 } & Total Measurement & $\mathbf{3 . 4 0}$ & $\mathbf{0 . 9 8}$ \\
\hline \multirow{5}{*}{ QWL } & The Moral Conditions of the Work Environment & 3.70 & 1.32 \\
& Job Characteristics & 3.68 & 1.27 \\
& Wages and Rewards & 3.77 & 1.23 \\
& Tam Work & 3.80 & 1.24 \\
& Head's Method in Supervision & 3.75 & 1.25 \\
& Participation in Decision-Making & 3.79 & 1.18 \\
\cline { 2 - 4 } & Total Measurement & $\mathbf{3 . 7 5}$ & $\mathbf{1 . 2 3}$ \\
\hline \multirow{5}{*}{ OCB } & Altruism & 3.65 & 1.22 \\
& Courtesy & 3.70 & 1.22 \\
& Sportsmanship & 3.64 & 1.31 \\
& Conscientiousness & 3.63 & 1.22 \\
& Civic virtue & 3.73 & 1.38 \\
\cline { 2 - 4 } & Total Measurement & $\mathbf{3 . 6 4}$ & $\mathbf{1 . 2 1}$ \\
\hline
\end{tabular}

Table 3 lists the mean and standard deviation among variables. The mean of each variable is more than 3 , and this result indicates that the study subjects in general have a higher level of PsyCap, QWL and OCB.

The different facets of PsyCap (hope, optimism, resilience and self-efficacy) are examined. Most respondents identified the presence of self-efficacy $(\mathrm{M}=3.60, \mathrm{SD}=0.971)$. This was followed by resilience $(\mathrm{M}=3.45, \mathrm{SD}=0.980)$, hope $(\mathrm{M}=3.30, \mathrm{SD}=1.16)$, and optimism $(\mathrm{M}=3.24, \mathrm{SD}=1.01)$.

The different facets of QWL (the moral conditions of the work environment, job characteristics, wages and rewards, team work, head's method in supervision, and participation in decision-making) are examined. Most respondents identified the presence of the moral conditions of the work environment $(\mathrm{M}=3.70, \mathrm{SD}=1.32)$. This was followed by job characteristics $(\mathrm{M}=3.68, \mathrm{SD}=1.27)$, wages and rewards $(\mathrm{M}=3.77, \mathrm{SD}=1.23)$, team work $(\mathrm{M}=3.80, \mathrm{SD}=1.24)$, head's method in supervision ( $\mathrm{M}=3.75, \mathrm{SD}=1.25)$, and participation in decision-making $(\mathrm{M}=3.79, \mathrm{SD}=1.18)$

The different facets of OCB (altruism, courtesy, sportsmanship, conscientiousness, and civic virtue) are examined. Most respondents identified the presence of altruism $(\mathrm{M}=3.65, \mathrm{SD}=1.22)$. This was followed by courtesy $(\mathrm{M}=3.70$, $\mathrm{SD}=1.22)$, sportsmanship $(\mathrm{M}=3.64, \mathrm{SD}=1.31)$, conscientiousness $(\mathrm{M}=3.63, \mathrm{SD}=1.22)$, and civic virtue $(\mathrm{M}=3.64$, $\mathrm{SD}=1.21)$ 


\subsection{Evaluating Reliability}

Table 4. Reliability of PsyCap, QWL and OCB

\begin{tabular}{llcc}
\hline Variables & \multicolumn{1}{c}{ The Dimension } & $\begin{array}{c}\text { Number of } \\
\text { Statement }\end{array}$ & ACC \\
\hline \multirow{5}{*}{ PsyCap } & 6 & 0.89 \\
& Hope & 6 & 0.80 \\
& Optimism & 6 & 0.80 \\
& Resilience & 6 & 0.77 \\
\hline \multirow{5}{*}{ QWL } & Self-Efficacy & $\mathbf{2 4}$ & $\mathbf{0 . 9 5}$ \\
\cline { 2 - 4 } & Total Measurement & 6 & 0.97 \\
& The Moral Conditions of the Work Environment & 6 & 0.96 \\
& Job Characteristics & 6 & 0.97 \\
& Wages and Rewards & 6 & 0.97 \\
& Tam Work & 6 & 0.95 \\
& Head's Method in Supervision & 6 & 0.94 \\
\hline \multirow{3}{*}{ OCB } & Participation in Decision-Making & $\mathbf{3 6}$ & $\mathbf{0 . 9 9}$ \\
\cline { 2 - 4 } & Total Measurement & 3 & 0.97 \\
& Altruism & 3 & 0.92 \\
& Courtesy & 3 & 0.95 \\
& Sportsmanship & 3 & 0.91 \\
& Conscientiousness & 3 & 0.95 \\
\hline & Civic virtue & $\mathbf{1 5}$ & $\mathbf{0 . 9 8}$ \\
\cline { 2 - 4 } & Total Measurement &
\end{tabular}

ACC was decided to exclude variables that had a correlation coefficient of less than 0.30 when the acceptable limits of ACC range from 0.60 to 0.80 , in accordance with levels of reliability analysis in social sciences (Nunnally \& Bernstein, 1994). To assess the reliability of the data, Cronbach's alpha test was conducted. Table 4 shows the reliability results for PsyCap, JE and OC. All items had alphas above 0.60 and were, therefore, excellent, according to Langdridge's (2004) criteria.

The 24 items of PsyCap are reliable because the ACC is 0.95 . The six items of hope scales are reliable due to the fact that the ACC is 0.89 . The optimism, which consists of six items, is reliable since the ACC is 0.80 . The six items related to resilience are reliable as ACC is 0.80 . Furthermore, the self-efficacy, which consists of six items, is reliable due to the fact that the ACC is 0.77 .

The 36 items of QWL are reliable because the ACC is 0.99 . The six items of the moral conditions of the work environment scales are reliable due to the fact that the ACC is 0.97 . The job characteristics, which consists of six items, is reliable since the ACC is 0.96. The six items related to wages and rewards are reliable as ACC is 0.97. Furthermore, the six items of team work scales are reliable due to the fact that the ACC is 0.97 . The head's method in supervision, which consists of six items, is reliable since the ACC is 0.95 . The six items related to participation in decision-making are reliable as ACC is 0.94 .

The 15 items of OCB are reliable due to the fact that the ACC is 0.98 . The altruism, which consists of three items, is reliable since the ACC is 0.97 while the three items related to courtesy is reliable as the ACC is 0.92 . Furthermore, the sportsmanship, which consists of three items, is reliable due to the fact that the ACC is 0.95 . The conscientiousness, which consists of three items, is reliable since the ACC is 0.91 while the three items related to civic virtue is reliable as the ACC is 0.95 .

\subsection{The Correlation among the Research Variables}

Table 5. Descriptive statistics and correlation matrix for all variables

\begin{tabular}{cccccc}
\hline Variables & Mean & $\begin{array}{c}\text { Std. } \\
\text { Deviation }\end{array}$ & PsyCap & QWL & OCB \\
\hline $\begin{array}{c}\text { Psychological } \\
\text { Capital }\end{array}$ & 3.40 & 0.98 & 1.000 & & \\
\hline $\begin{array}{c}\text { Quality } \\
\text { of Work life }\end{array}$ & 3.74 & 1.23 & $0.439^{* *}$ & 1.000 & \\
\hline $\begin{array}{c}\text { Organizational } \\
\text { Citizenship Behavior }\end{array}$ & 3.64 & 1.21 & $0.390^{* *}$ & $0.969^{* *}$ & 1.000 \\
\hline
\end{tabular}


Table 5 shows correlation coefficients between the research variables, and results indicate the presence of significant correlation between variables (PsyCap, QWL and OCB).

The level of PsyCap of employees is average (Mean=3.30; $\mathrm{SD}=0.98$ ), while QWL is higher (Mean=3.74; SD 1.23) which led to high level of OCB (Mean=3.64; SD. 1.21).

Table 5 reveals the existence of a positive correlation between PsyCap and QWL $(\mathrm{R}=0.449$; $\mathrm{P}<0.01)$, which means that the high level of PsyCap leads to higher QWL.

The table shows the existence of a positive correlation between PsyCap and OCB $(\mathrm{R}=0.390 ; \mathrm{P}<0.01)$, which means that the high level of PsyCap leads to higher OCB.

Finally, Table 5 refers to the existence of a positive correlation between QWL and OCB $(\mathrm{R}=0.969 ; \mathrm{P}<0.01)$ implying that the high level of QWL led to high level of OCB.

\subsection{The Relationship between PsyCap (Hope) and QWL}

Table 6. MRA results for PsyCap (hope) and QWL

\begin{tabular}{llcc}
\hline \multicolumn{1}{c}{ The Variables of PsyCap (Hope) } & Beta & $\mathrm{R}$ & $\mathrm{R}^{2}$ \\
\hline 1. When I find myself under pressure, I think how to get out of this & 0.16 & 0.33 & 0.11 \\
predicament. & 0.05 & 0.29 & 0.08 \\
2. I have a strong will to achieve my goals. & $0.28^{* *}$ & 0.22 & 0.05 \\
3. I have several alternatives to resolve any problem I may face. & $0.28^{* *}$ & 0.31 & 0.10 \\
4. I feel that I have achieved great success in my career. & $0.25^{*}$ & 0.39 & 0.15 \\
5. I can think of more than one way to achieve my goals. & 0.02 & 0.38 & 0.14 \\
6. I have achieved most of goals I have persued. & & 0.45 & \\
\hline - Multiple Correlation Coefficients (MCC) & & 0.21 & \\
- Determination of Coefficient (DF) & & 13.60 & \\
- The Value of Calculated F & & 2.308 & \\
- Degree of Freedom & & 0.01 & \\
- The Value of Indexed F & & & \\
- Level of Significance & & & \\
\hline$* \mathrm{P}<.05$ & & &
\end{tabular}

According to Table 6, the regression-coefficient between PsyCap (Hope) and QWL is $\mathrm{R}=0.46$ and $\mathrm{R} 2=0.21$. This means that the QWL can be explained by the dimensions of PsyCap (Hope), for example, "I have several alternatives to resolve any problem I may face" $(\beta=0.286, R=0.224$, and $R 2=0.050)$, "I feel that I have achieved great success in my career" $(\beta=0.289, \mathrm{R}=0.318$, and $\mathrm{R} 2=0.101)$, and "I can think of more than one way to achieve my goals" ( $\beta=$ $0.254, \mathrm{R}=0.397$, and $\mathrm{R} 2=0.156$ ).

Because of the calculated F (13.60) more than indexed F (2.80) at the statistical significance level of 0.01, the null hypothesis is rejected.

6.4 The Relationship between Psycap (Optimism) and QWL

Table 7. The relationship between PsyCap (optimism) and QWL

\begin{tabular}{|c|c|c|c|}
\hline The Variables of PsyCap (Optimism) & Beta & $\mathrm{R}$ & $\mathrm{R}^{2}$ \\
\hline 1. When I'm not sure of something, I usually expect the best. & 0.05 & 0.19 & 0.04 \\
\hline 2. I can easily feel relaxed. & 0.10 & 0.33 & 0.11 \\
\hline $\begin{array}{l}\text { 3. When I feel indignant on the performance of the work, I delay it for } \\
\text { another time. }\end{array}$ & $0.10^{*}$ & 0.20 & 0.04 \\
\hline 4. I am always optimistic about my future. & 0.06 & 0.31 & 0.10 \\
\hline 5. I expect events to ensure continuity in achieving my goals. & 0.09 & 0.39 & 0.15 \\
\hline 6. I expect pleasant events, rather than unpleasant ones. & 0.18 & 0.38 & 0.15 \\
\hline - Multiple Correlation Coefficients (MCC) & & 0.44 & \\
\hline - Determination of Coefficient (DF) & & 0.19 & \\
\hline - The Value of Calculated F & & 12.35 & \\
\hline - Degree of Freedom & & 6,308 & \\
\hline - The Value of Indexed F & & 2.80 & \\
\hline - Level of Significance & & 0.01 & \\
\hline
\end{tabular}


According to Table 7, the regression-coefficient between PsyCap (Optimism) and QWL is R=0.44 and R2=0.19. This means that the QWL can be explained by the dimensions of PsyCap (Optimism), for example, "When I feel indignant on the performance of the work, I delay it for another time" $(\beta=0.10, R=0.20$, and $R 2=0.04)$, "I expect pleasant events, rather than unpleasant events" $(\beta=0.18, \mathrm{R}=0.38$, and $\mathrm{R} 2=0.15)$, and "I expect events to ensure continuity in achieving my goals" $(\beta=0.09, \mathrm{R}=0.39$, and $\mathrm{R} 2=0.15)$. Thus, the null hypothesis is rejected because PsyCap (Optimism) and QWL have a statistical relationship at the significance level of 0.01 .

\subsection{The Relationship between PsyCap (Resilience) and QWL}

Table 8. The relationship between PsyCap (resilience) and QWL

\begin{tabular}{lccc}
\hline \multicolumn{1}{c}{ The Variables of PsyCap (Resilience) } & Beta & $\mathrm{R}$ & $\mathrm{R}^{2}$ \\
\hline 1. I restore my normal mood quickly after unpleasant events. & $0.20^{* *}$ & 0.18 & 0.03 \\
2. I enjoy dealing with new and unusual events. & 0.11 & 0.33 & 0.11 \\
3. I usually succeed to form positive impression about others. & $0.10^{*}$ & 0.22 & 0.05 \\
4. I prefer following more than one route to achieve goals. & 0.12 & 0.32 & 0.11 \\
5. I prefer work that is both new and challenging. & $0.52^{* *}$ & 0.38 & 0.15 \\
6. I overcome feelings of anger that I may have toward a particular & $0.19^{*}$ & 0.29 & 0.15 \\
person. & & 0.44 \\
\hline - Multiple Correlation Coefficients (MCC) & & 0.19 & \\
- Determination of Coefficient (DF) & & 12.62 & \\
- The Value of Calculated F & 6,308 & \\
- Degree of Freedom & & 2.80 & \\
- The Value of Indexed F & & 0.01 & \\
- Level of Significance & & &
\end{tabular}

According to Table 8, the regression-coefficient between PsyCap (Resilience) and QWL is R=0.44 and R2=0.19. This means that the QWL can be explained by the dimensions of PsyCap (Resilience), for example, "I prefer work that is both new and challenging" $(\beta=0.52, \mathrm{R}=0.38$, and $\mathrm{R} 2=0.15)$, "I restore my normal mood quickly after unpleasant events" $(\beta=0.20, \mathrm{R}=0.18$, and $\mathrm{R} 2=0.03)$, and "I prefer following more than one route to achieve goals" ( $\beta=0.12, R=0.32$, and $R 2=0.11$ ). Therefore, there is enough empirical evidence to reject the null hypothesis.

\subsection{The Relationship between PsyCap (Self-Efficacy) and QWL}

Table 9. The relationship between PsyCap (self-efficacy) and QWL

\begin{tabular}{|c|c|c|c|}
\hline The Variables of PsyCap (Self-Efficacy) & Beta & $\mathrm{R}$ & $\mathrm{R}^{2}$ \\
\hline I enjoy a great deal of self-confidence. & $0.22^{*}$ & 0.23 & 0.05 \\
\hline I'm in the best mood when I'm actually in a situation of challenge. & 0.09 & 0.22 & 0.05 \\
\hline I face many problems and I can solve them. & $0.14^{*}$ & 0.21 & 0.04 \\
\hline I prefer self-reliance to find a solution when things go wrong. & 0.07 & 0.32 & 0.11 \\
\hline I think that I have a very good chance to realize my goals in life. & 0.15 & 0.39 & 0.16 \\
\hline I finish my work on time and do not wait until the last minute. & 0.17 & 0.38 & 0.15 \\
\hline - Multiple Correlation Coefficients (MCC) & & 0.45 & \\
\hline - Determination of Coefficient (DF) & & 0.21 & \\
\hline - The Value of Calculated F & & 12.96 & \\
\hline - Degree of Freedom & & 6,308 & \\
\hline - The Value of Indexed F & & 2.80 & \\
\hline - Level of Significance & & 0.01 & \\
\hline
\end{tabular}

According to Table 9, the regression-coefficient between PsyCap (Self-Efficacy) and QWL is R=0.45 and R2=0.21. This means that the QWL can be explained by the dimensions of PsyCap (Self-Efficacy), for example, "I enjoy a great deal of self-confidence" $(\beta=0.22, \mathrm{R}=0.23$, and $\mathrm{R} 2=0.05)$, "I finish my work on time and do not wait until the last minute" ( $\beta=0.17, \mathrm{R}=0.38$, and $\mathrm{R} 2=0.15)$, and "I face many problems and I could solve them" $(\beta=0.14, \mathrm{R}=0.21$, and R2=0.04). Thus, the null hypothesis is rejected because PsyCap (Self-Efficacy) and QWL have a statistical relationship at the significance level of 0.01 . 


\subsection{The Relationship between PsyCap (Hope) and OCB}

Table 10. MRA results for PsyCap (hope) and OCB

\begin{tabular}{lccc}
\hline \multicolumn{1}{c}{ The Variables of PsyCap (Hope) } & Beta & $\mathrm{R}$ & $\mathrm{R}^{2}$ \\
\hline 1. When I find myself under pressure, I think how to get out of this & 0.19 & 0.32 & 0.09 \\
predicament. & 0.04 & 0.27 & 0.07 \\
2. I have a strong will to achieve my goals. & $0.34^{* *}$ & 0.19 & 0.03 \\
3. I have several alternatives to resolve any problem I may face. & $0.29^{* *}$ & 0.27 & 0.07 \\
4. I feel that I have achieved great success in my career. & 0.17 & 0.35 & 0.12 \\
5. I can think of more than one way to achieve my goals. & 0.09 & 0.36 & 0.13 \\
6. I have achieved most of goals I have persued. & & 0.43 & \\
\hline - Multiple Correlation Coefficients (MCC) & & 0.19 & \\
- Determination of Coefficient (DF) & & 6,308 & \\
- The Value of Calculated F & & 2.80 & \\
- Degree of Freedom & & 0.01 & \\
- The Value of Indexed F & & & \\
- Level of Significance & &
\end{tabular}

According to Table 10, the regression-coefficient between PsyCap (Hope) and OCB is $\mathrm{R}=0.43$ and $\mathrm{R} 2=0.19$.

This means that the OCB can be explained by the dimensions of PsyCap (Hope), for example, "I have several alternatives to resolve any problem I may face" $(\beta=0.34, \mathrm{R}=0.19$, and $\mathrm{R} 2=0.03)$, "I feel that I have achieved great success in my career" $(\beta=0.29, \mathrm{R}=0.27$, and $\mathrm{R} 2=0.07)$, and "I can think of more than one way to achieve my goals" $(\beta=0.17, \mathrm{R}=0.35$, and $\mathrm{R} 2=0.12)$.

Because of the calculated F (11.79) more than indexed F (2.80) at the statistical significance level of 0.01 , the null hypothesis is rejected.

\subsection{The Relationship between PsyCap (Optimism) and $O C B$}

Table 11. The relationship between PsyCap (optimism) and OCB

\begin{tabular}{lccc}
\hline \multicolumn{1}{c}{ The Variables of PsyCap (Optimism) } & Beta & $\mathrm{R}$ & $\mathrm{R}^{2}$ \\
\hline 1. When I'm not sure of something, I usually expect the best. & 0.01 & 0.13 & 0.02 \\
2. I can easily feel relaxed. & 0.11 & 0.30 & 0.09 \\
3. When I feel indignant on the performance of the work, I delay it & 0.08 & 0.17 & 0.03 \\
for another time. & 0.04 & 0.27 & 0.07 \\
4. I am always optimistic about my future. & 0.01 & 0.35 & 0.12 \\
5. I expect events to ensure continuity in achieving my goals. & $0.28^{*}$ & 0.36 & 0.13 \\
6. I expect pleasant events, rather than unpleasant ones. & & 0.40 & \\
\hline - Multiple Correlation Coefficients (MCC) & & 0.16 & \\
- Determination of Coefficient (DF) & & 6.77 & \\
- The Value of Calculated F & & 2.308 & \\
- Degree of Freedom & & 0.01 & \\
- The Value of Indexed F & & & \\
- Level of Significance & &
\end{tabular}

According to Table 11, the regression-coefficient between PsyCap (Optimism) and OCB is $\mathrm{R}=0.40$ and $\mathrm{R} 2=0.16$. This means that the OCB can be explained by the dimensions of PsyCap (Optimism), for example, "I expect pleasant events, rather than unpleasant events" ( $\beta=0.28, \mathrm{R}=0.36$, and $\mathrm{R} 2=0.13)$, "I can easily feel relaxed" ( $\beta=0.11, \mathrm{R}=0.30$, and R2=0.09), and "When I feel indignant on the performance of the work, I delay it for another time" $(\beta=0.01, \mathrm{R}=$ 0.13 , and $\mathrm{R} 2=0.02$ ).

Thus, the null hypothesis is rejected because PsyCap (Optimism) and OCB have a statistical relationship at the significance level of 0.01 . 


\subsection{The Relationship between PsyCap (Resilience) and OCB}

Table 12. The relationship between PsyCap (resilience) and OCB

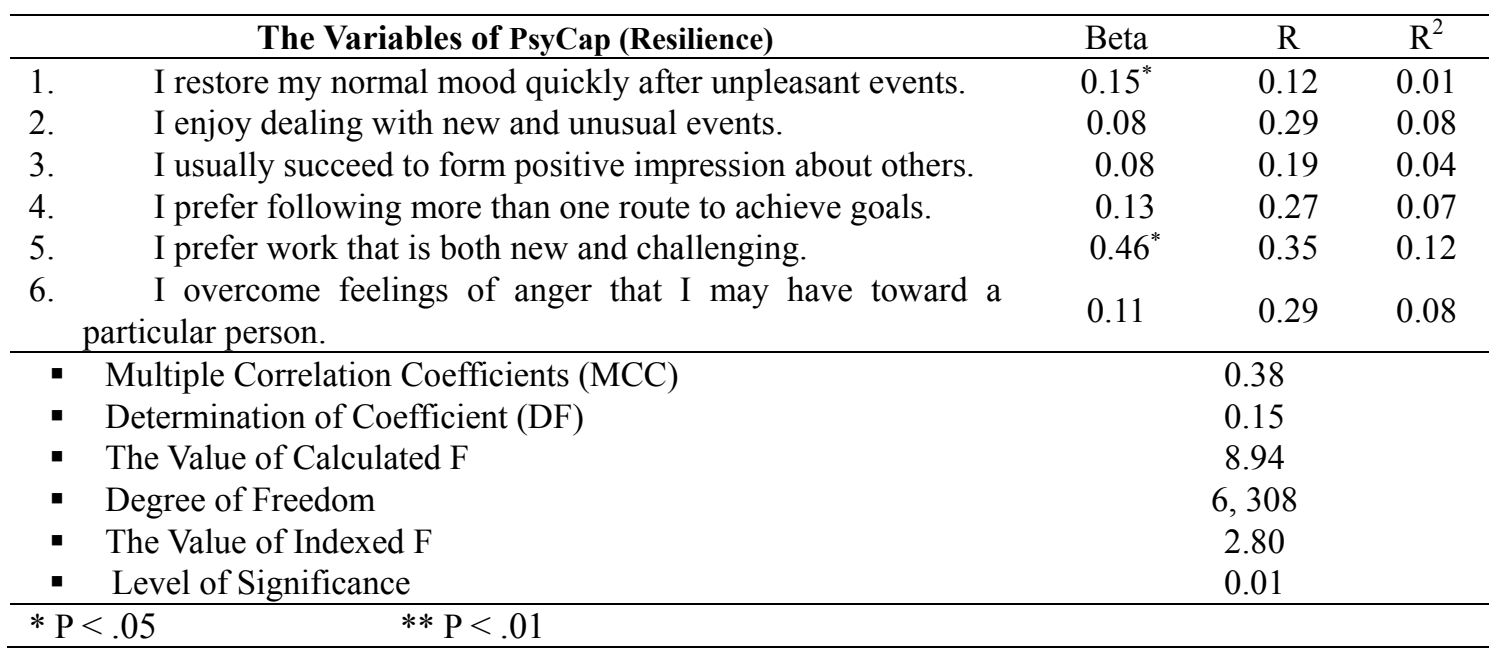

According to Table 12, the regression-coefficient between PsyCap (Resilience) and OCB is $\mathrm{R}=0.38$ and $\mathrm{R} 2=0.15$. This means that the OCB can be explained by the dimensions of PsyCap (Resilience), for example, "I restore my normal mood quickly after unpleasant events" $(\beta=0.15, \mathrm{R}=0.12$, and $\mathrm{R} 2=0.01)$, and "I prefer work that is both new and challenging" $(\beta=0.46, \mathrm{R}=0.35$, and $\mathrm{R} 2=0.12)$. Therefore, there is enough empirical evidence to reject the null hypothesis.

6.10 The Relationship between PsyCap (Self-Efficacy) and OCB

Table 13. The relationship between PsyCap (self-efficacy) and OCB

\begin{tabular}{llcc}
\hline The Variables of PsyCap (Self-Efficacy) & Beta & $\mathrm{R}$ & $\mathrm{R}^{2}$ \\
\hline 1. I enjoy a great deal of self-confidence. & 0.19 & 0.22 & 0.05 \\
2. I'm in the best mood when I'm actually in a situation of challenge. & 0.08 & 0.20 & 0.04 \\
3. I face many problems and I can solve them. & $0.13^{*}$ & 0.18 & 0.03 \\
4. I prefer self-reliance to find a solution when things go wrong. & 0.05 & 0.27 & 0.07 \\
5. I think that I have a very good chance to realize my goals in life. & 0.05 & 0.35 & 0.12 \\
6. I finish my work on time and do not wait until the last minute. & $0.26^{*}$ & 0.36 & 0.13 \\
\hline - Multiple Correlation Coefficients (MCC) & 0.41 \\
- Determination of Coefficient (DF) & 0.17 \\
- The Value of Calculated F & 10.31 \\
- Degree of Freedom & 6,308 \\
- The Value of Indexed F & 2.80 \\
- Level of Significance & & 0.01 \\
\hline$*$ P $<.05$ & \multicolumn{2}{c}{}
\end{tabular}

According to Table 13, the regression-coefficient between PsyCap (Self-Efficacy) and OCB is $\mathrm{R}=0.41$ and $\mathrm{R} 2=0.17$. This means that the OCB can be explained by the dimensions of PsyCap (Self-Efficacy), for example, "I finish my work on time and do not wait until the last minute" $(\beta=0.26, \mathrm{R}=0.36$, and $\mathrm{R} 2=0.13)$, "I enjoy a great deal of self-confidence" $(\beta=0.19, R=0.22$, and $R 2=0.05)$, and "I face many problems and I could solve them" $(\beta=0.13, R=$ 0.18 , and $\mathrm{R} 2=0.03)$.

Thus, the null hypothesis is rejected because PsyCap (Self-Efficacy) and OCB have a statistical relationship at the significance level of 0.01 .

\section{Research Finding}

The findings support the view that the dimensions of PsyCap (hope, optimism, resilience, and self-efficacy) were positively related with QWL at Sadat City University. More PsyCap is more effective in achieving QWL. High PsyCap will be more likely to achieve high OCB. 
The high PsyCap would lead to better group communication, more satisfaction of the group members, QWL and more OCB at Sadat City University.

The results of this research refer to a direct exponential influence relationship between the PsyCap and QWL among employees at Sadat City University, as the low level of PsyCap reduced their agreement with the Sadat City University.

The results support the view that PsyCap is one of constructs contributing to the formation and increasing of QWL. The results are consistent with research conducted by Mortazavi, et al., 2012.

Several meta analytic studies have found a negative relationship between PsyCap and OCB. The findings reveal that PsyCap among employees positively influences OCB.

Our findings support the view that PsyCap is a significant predictor of OCB of executives. The results are consistent with research conducted by Murthy, 2014.

\section{Recommendation}

1. The need to focus on the four dimensions of PsyCap and use them to increase the QWL and OCB among employees.

- Hope, it is found out, affects the attitudes of employees and then influences the QWL they have, where high levels of hope make employees contribute to the increase of OCB.

- As for resilience, we find out that an individual's ability to adapt and be flexible may affect the QWL. Individuals who have a high capacity and flexibility to cope with stressful circumstances might have higher feelings of OCB.

- As for optimism, we find that the level of an individual affects the level of his ability to deal with adverse events in the work environment and then controls the feelings of OCB towards the organization.

- As for the last dimension of self-efficacy, we find that the decline in self-efficacy makes an individual contribute significantly to the increase of OCB towards the organization. Also, we find that the higher self-efficacy is, the higher of QWL.

2. The need to train managers on how to develop the four dimensions of PsyCap through training courses targeting the spread of the spirit of hope and optimism among managers, and equipping them with skills to deal with different situations in order to ensure the achievement of positive feedback in the work environment.

3. Sadat City University managers and leaders must attend development of the PsyCap as competitive advantage that can actualize very important goals such as reinforcement of meaning in work, OCB, commitment, and performance.

4. Managing and increasing the level of PsyCap in Sadat City University require deliberate interventions. For example, organizations can increase the level of PsyCap by using short training sessions of one to three hour micro interventions in which they measure PsyCap before and after the interventions.

5. Sadat City University can increase PsyCap through Strengths, Opportunities, Aspirations and Results (SOAR) a strategic thinking framework that integrates whole system and strengths-based perspectives to create a strategic transformation process with a focus on creating sustainable value to achieve desired performance results.

\section{Limitations and Future Research}

This research focuses on the components of psychological factors of people, that is, PsyCap. Incorporating trait-like components such as psychological hardiness, personality of personnel will provide further insights into the role of psychological aspects of people in their effort for promoting QWL. This is also an appropriate area for future research. There is a need to accomplish subsequent research in other industries, similar industries or other treatment invigorate our hypothesizes. Confirming these results in other industrial settings to reinforce them.

\section{Conclusion}

One of the most important factors that play a positive role is PsyCap of human resource of an organization. Then, in this research, we try to test this assumption until help managers to invest on PsyCap of their organization and improve QWL and OCB.

Mirkamali \& Narenji Thani (2011) identify the factors related to faculty QWL which are of great importance, because they have positive and significant relation with job satisfaction. Therefore, we can improve job satisfaction by changing and manipulating QWL factors, and thus move toward the development of the organization. 
Woolf (2004) suggests few ways to help people create QWL. They are as follows:

1. An individual must create a personal vision by articulating something to be accomplished in career. Such vision will set a target of where an individual wants to be in life and must be prepared to make adjustment at any time. Employees need to be flexible and ready as life's journey is all about twists and turns. It keeps employees focus and strives towards their vision and when they pull off, it will be a meaningful accomplishment.

2. An individual must not perplex real identity with role played at work. Let the vision manifest who each individual really. The role played at work is intended for the work game. It does not replicate true identity. To guarantee job satisfaction, employees must let their vision lead them.

3. Individuals must develop healthy personal habits by taking care of their body, mind and spirit to withstand all those challenges and pressures they face at work. Eating habits, sleeping routines and exercising will help employees live a healthy life style and resilient enough to face anything coming. It helps employees to be positive and accept almost everything in a positive way.

PsyCap can create a situation that promotes QWL. These contributions can be provided based on this point. Having a favorite level of PsyCap in totality and in framework of its dimensions (hope, optimism, resiliency and self-efficacy) can provide situation that personnel can provide needs of survival, belonging and knowledge (QWL) and improve their performance in workplace. For example, a hopeful (as a element of PsyCap) employee can create a career vision of where he/she wants to be in life. A resilient person withstands all those challenges and pressures at work.

Research shows that PsyCap is a more state-like factor than personality traits, that is, it is more open to be developed and managed (Luthans et al. 2008). Therefore, recruiting employees with high levels of PsyCap and establishing appropriate human resource policies and practice to further develop employees' PsyCap (hope, optimism, resiliency and self-efficacy) are desirable for University.

University could enhance the performance of its employees, leading to an increase in university performance. This also improves employees' QWL, which is a critical factor for productivity (Wright \& Cropanzano 2004).

Mirkamali \& Narenji Thani (2011) discuss identifying the factors related to faculty QWL. This is of great importance because it has positive and significant relation with JS. Therefore, we can improve JS by changing and manipulating QWL factors, and thus move toward the development of the organization.

\section{References}

Avey, J. B., Reichard, R. J., Luthans, F., \& Mhatre, K. H. (2011). Meta-analysis of the Impact of Positive Psychological Capital on Employee Attitudes, Behaviors, and Performance. Human Resource Development Quarterly, 22(2), 127-152. http://dx.doi.org/10.1002/hrdq.20070

Avey, J., Luthans, F., \& Palmer, N. (2010). Impact of Positive Psychological Capital on Employee Well-Being Over Time. Journal of Occupational Health Psychology, 15(1), 17-28. http://dx.doi.org/10.1037/a0016998

Avey, J., Luthans, F., \& Youssef, C. (2008). The Additive Value of Positive Psychological Capital in Predicting Work Attitudes and Behaviors, Leadership Institute Faculty Publications. Paper 6. Retrieved from http://digitalcommons.unl.edu/leadershipfacpub/6

Beauregard, T.A. (2007). Family Influences on the career life cycle. Career Choice in Mangement and Entrepreneurship: A Research Companion, 101-126.

Berry, L.L., \& A. Parasuraman. (1991). Marketing Service, Competing through Quality. The Free Press, New York.

Borman, C., Penner, L., Allen, T., \& Motowidlo, S. T. (2001). Personality Predictors of Citizenship Performance. International Journal of Selection and Assessment, 9(1/2), 52-66. http://dx.doi.org/10.1111/1468-2389.00163

Borman, W. C., \& Motowidlo, S. J. (1993). Expanding the criterion domain to include elements of contextual performance. In N. Schmitt \& W. C. Borman (Eds.), Personnel selection in organizations (pp. 71-98). San Francisco: Jossey Bass.

Cho, D., \& Son, J. (2012). Job Embeddedness and Turnover Intentions: An Empirical Investigation of Construction IT Industries. International Journal of Advanced Science and Technology, 40, 101-110.

Cohen, A., \& Vigoda, E. (2000). Do good citizens make good organizational citizens? An empirical examination of the relationship between general citizenship and organizational citizenship behavior in Israel. Administration and Society, 32, 596- 625. http://dx.doi.org/10.1177/00953990022019597 
Efraty, D., Sirgy, M.J., \& Claiborne, C.B. (1991). The effects of personal alienation on organizational identification: a quality-of-work life model. J Bus Psychol, 6(Fall), 57-78. http://dx.doi.org/10.1007/BF01013685

Ehrhart, M., \& Naumann, S. (2004). Leadership and Procedural Justice Climate Citizenship Behavior as Antecedents of Unit-Level Organizational. Personnel $\quad$ Psychology, $\quad$ 57, http://dx.doi.org/10.1111/j.1744-6570.2004.tb02484.x

Erturk, A., Yılmaz, C., \& Ceylan, A. (2004). Promoting Organizational Citizenship Behaviors: Relative Effects of Job Satisfaction, Organizational Commitment, and Perceived Managerial Fairness, METU Studies in Development, 31, 89-210.

Etebarian, A., Tavakoli, S., \& Abzari, M. (2012). The relationship between psychological capital and organizational commitment. African Journal of Business Management, 6(14), 5057-5060.

Greene, J. (2012). Job Embeddedness: Do the Interaction Effects of Attitude, Personality, and Exchange Relationships Detract from Performance?, Dissertations, Theses and Capstone Projects. Paper 504.

Harris, K.J., Wheeler, A.R., \& Kacmar, K.M. (2011). The Mediating Role of Organizational Job Embeddedness in the LMX-outcomes Relationships. Leadersh.Q., 22(2), 271-281. http://dx.doi.org/10.1016/j.leaqua.2011.02.003

Havlovic, S.J. (1991). Quality of work life and human resource outcomes. Industrial Relations, 30(3), 469-479. http://dx.doi.org/10.1111/j.1468-232X.1991.tb00799.x

Heskett, J.L., Sasser, W.E. Jr., \& Schlesinger, L.A. (1997). The Service Profit Chain. The Free Press, New York.

Hian, C.C., \& Einstein, W.O. (1990). Quality of work life (QWL): What can unions do?. S.A.M. Advanced Management Journal, 55(2), 17-22.

Holtom, B. C., \& O'Neill, B. S. (2004). Job embeddedness: A theoretical foundation for developing a comprehend sive nurse retention plan. Journal of Nursing Administration, 34, 216-227. http://dx.doi.org/10.1097/00005110-200405000-00005

Khattak, F., Hussain, A., Mehmood, Q., Mumtaz, A., Rehman, U., Kasif, U., \& Rehman, K. (2012). Shrinking Employees Turnover Intention by applying Tools of Job Embeddedness (Used as a Mediator). Information Management and Business Review, 4(7), 370-378.

Larson, M., \& Luthans, F. (2006). Potential Addes Value of Psychological Capital in Predicting Work Attitudes. Journal of Leadership and Organizational Studies, 13(1), 45-62. http://dx.doi.org/10.1177/10717919070130010701

Lee, T. W., Mitchell, T. R., Sablynski, C. J., Burton, J. P., \& Holtom, B. C. (2004). The effects of job embeddedness on organizational citizenship, job performance, volitional absences, and voluntary turnover. Academy of Management Journal, 47, 711-722. http://dx.doi.org/10.2307/20159613

Levine, M.F., Taylor, J., \& Davis, L. (1984). Defining quality of work life. Human Relations, 37(1), 81-104. http://dx.doi.org/10.1177/001872678403700105

Luthans, F., Avolio, B., Walumbwa, F., \& Li, W. (2005). The psychological capital of Chinese workers: Exploring the relationship with performance. Management and Organization Review, 1, 247-269. http://dx.doi.org/10.1111/j.1740-8784.2005.00011.x

Luthans, F., \& Youssef, C. (2004). Human, Social, and Now Positive Psychological Capital Management: Investing in People for Competitive Advantage. Organizational Dynamics, 33(2), 143-160. http://dx.doi.org/10.1016/j.orgdyn.2004.01.003

Luthans, F., Avey, J. B., \& Patera, J. L. (2008). Experimental analysis of a web-based training intervention to develop psychological capital. Academy of Management Learning and Eduction, 7, 209-221. http://dx.doi.org/10.5465/AMLE.2008.32712618

Luthans, F., Avey, J.B., Avolio, B.J., Norman, S., \& Combs, G. (2006). Psychological capital development: Toward a micro-intervention. Journal of Organizational Behavior, 27, 387-393. http://dx.doi.org/10.1002/job.373

Luthans, F., Norman, S. M., Avolio, B. J., \& Avey, J. B. (2008). Supportive climate and organizational success: The mediating role of psychological capital. Journal of Organizational Behavior, 29(2), 219-238. http://dx.doi.org/10.1002/job.507

Luthansa, F., Aveyb, J., Clapp-Smitha R., \& Lia, W. (2008). More evidence on the value of Chinese workers' psychological capital: A potentially unlimited competitive resource? The International Journal of Human 
Resource Management, 19(5), 818-827. http://dx.doi.org/10.1080/09585190801991194

MacKenzie, S., Podsakoff, M., \& Fetter, R. (1993). The Impact of Organizational Citizenship Behavior on Evaluations of Salesperson Performance. Journal of Marketing, 57, 70-80. http://dx.doi.org/10.2307/1252058

Marta, J., Singhapakdi, A., Lee, D.J., Sirgy, M.J., Koonmee, K., \& Virakul, B. (2011). Perceptions about ethics institutionalization and quality of work life: Thai versus American marketing managers. Journal of Business Research. http://dx.doi.org/10.1016/j.jbusres.2011.08.019

Masten, A.S., \& Reed, M. (2002). Resilience in development. In C.R. Snyder \& S.J. Lopez, (Eds.), Handbook of Positive Psychology (pp. 74-88). Oxford University Press, London.

Mathur, R. N. (1989). Quality of working life of women construction workers. Commonwealth Publishers, New Delhi, India.

Mitchell, T.R., Holtom, B.C., Lee, T.W., Sablynski, C.J., \& Erez, M. (2001). Why People Stay: Using Job Embeddedness to Predict Voluntary Turnover. Academy of Management Journal, 44(6), 1102-1121. http://dx.doi.org/10.2307/3069391

Mortazavi, S., Yazdi, S., \& Amini, A. (2012). The Role of the Psychological Capital on Quality of Work Life and organization performance. Interdisciplinary Journal of Contemporary Research in Business, 4(2), 206-217.

Murthy, R. (2014). Psychological Capital, Work Engagement and Organizational Citizenship Behaviour. Sinhgad Institute of Management and Computer Application (SIMCA), pp.347-358.

Nemeth, C., \& Staw, B. (1989). The Tradeoffs of Social Control and Innovation in Small Groups and Organizations. In L. Berkowitz (Ed.), Advances in Experimental Social Psychology (Vol. 22, pp. 175-210). New York: Academic Press.

Norman, S.M., Avey, J.B., Nimnicht, J.L., \& Pigeon, N.G. (2010). The Interactive Effects of Psychological Capital and Organizational Identity on Employee Organizational Citizenship and Deviance Behaviors. Journal of Leadership \& Organizational Studies, 17(4), 380-391. http://dx.doi.org/10.1177/1548051809353764

Organ, D. W. (1988). Organizational Citizenship Behavior: The Good Soldier Syndrome. Lexington, MA: Lexington Books.

Organ, D., \& Ryan, K. (1995). A Meta-Analytic Review of Attitudinal and Dispositional Predictors of Organizational $\begin{array}{lllll}\text { Citizenship Behavior. } & \text { Personnel } & \text { Psychology, } & 48(4), & \end{array}$ http://dx.doi.org/10.1111/j.1744-6570.1995.tb01781.x

Paine, J., \& Organ, D. (2000). The Cultural Matrix of Organizational Citizenship Behavior: Some Preliminary Conceptual and Empirical Observations. Human Resource Management Review, 10(1), 45-59. http://dx.doi.org/10.1016/S1053-4822(99)00038-8

Podsakoff, M., \& MacKenzie, S. (1997). Impact of Organizational Citizenship Behavior on Organizational Performance: A Review and Suggestions for Future Research. Human Performance 10(2), 133-151. http://dx.doi.org/10.1207/s15327043hup1002_5

Podsakoff, M., MacKenzie, S., Moorman, R., \& Richard, F. (1990). Transformational Leader Behaviors and Their Effects on Followers' Trust in Leader, Satisfaction, and Organizational Citizenship Behaviors. Leadership Quarterly, 1(2), 107-142. http://dx.doi.org/10.1016/1048-9843(90)90009-7

Podsakoff, M., MacKenzie, S., Paine, J., \& Bachrach, D. (2000). Organizational Citizenship Behaviors: A Critical Review of the Theoretical and Empirical Literature and Suggestions for Future Research. Journal of Management, 26(3), 513-563. http://dx.doi.org/10.1177/014920630002600307

Podsakoff, P. M., MacKenzie, S. B., \& Hui, C. (1993). Organizational Citizenship Behaviours and Managerial Evaluations of Employee Performance: A Review and Suggestions for Future Research. Research in Personnel and Human Resources Management, 11, 1-40.

Ravichandran, S., Gilmore, S. A., \& Strohbehn, C. (2007). Organizational Citizenship Behavior Research in Hospitality: Current Status and Future Research Directions. Journal of Human Resources in Hospitality and Tourism, 6(2), 59-77. http://dx.doi.org/10.1300/J171v06n02_04

Reitz, O., \& Anderson, M. (2011). An Overview of Job Embeddedness. Journal of Professional Nursing, 27(5), 320-327. http://dx.doi.org/10.1016/j.profnurs.2011.04.004

Robbins, S. P. (1989). Organizational Behavior: Concepts, Controversies, and Applications. NJ: Prentice Hall. 
Robins, G., \& Wiersema, R. (1995). Organization \& Behavior. Princeton, New Jersey.

Scobel, D. N. (1975). Doing away with the factory blue. Harvard Business Review, 53, 132-142.

Seligman, M. (2002). Positive Psychology, Positive, Prevention and Positive Therapy. In Handbook of Positive Psychology (pp.3-9). Oxford University Press, New York.

Sin, N.L., \& Lyubomirsky, S (2009). Enhancing well-being and alleviating depressive symptoms with positive psychology interventions: A practice-friendly meta-analysis. Journal of Clinical Psychology, 65, 467-487. http://dx.doi.org/10.1002/jclp.20593

Sirgy, M.J., Efraty, D., Siegel, P., \& Lee, D.J. (2001). A new measure of quality of work life (QWL) based on need satisfaction and spillover theory. Social Indicators Research, 55(3), 241-302. http://dx.doi.org/10.1023/A:1010986923468

Srinivas, E.S. (1994). Perceived quality of work life (PQWL) and organizational commitment: A study of managers in selected organizations. Management Research: Contemporary Issues. New Delhi, South Asia Publications.

Straw, R.J., \& Heckscher, C.C. (1984). QWL: new working relationships in the communication industry. Labor Studies Journal, 8(3), 261-274.

Turnipseed, D., \& Rassuli, A. (2005). Performance Perceptions of Organizational Citizenship Behaviors at Work: A bi-level Study among Managers and Employees. British Journal of Management, 16, 231-244. http://dx.doi.org/10.1111/j.1467-8551.2005.00456.x

Walton, R.E. (1974). QWL indicators: prospects and problems. Measuring the quality of working life. A symposium on Social Indicators of Working Life. Ottawa, March, 19-20.

Williams L., \& Anderson, S. (1991). Job Satisfaction and Organizational Commitment as Predictors of Organizational Citizenship and In-Role Behaviors. Journal of Management, 17(3), 601-617. http://dx.doi.org/10.1177/014920639101700305

Youssef, C.M., \& Luthans, F. (2007). Positive organizational behavior in the workplace: The Impact of Hope, Optimism, and Resilience. Journal of Management, 33, 774-800. http://dx.doi.org/10.1177/0149206307305562 